\title{
Living Values Education in Civic Education Learning to Develop Students' Civic Disposition
}

\author{
Kokom Komalasari \\ Department of Civic Education \\ Universitas Pendidikan Indonesia \\ Bandung, Indonesia \\ kokom@upi.edu
}

\begin{abstract}
This study aimed at describing a model of living values education (LVE) in Civic Education Learning and its impact on the civic disposition of students. This study used Research and Development design in senior high schools in Bandung. The technique of data collection used observation, documentation, focus group discussion and questionnaire. The analysis of qualitative data used data collection, data reduction, data presentation and conclusion stages. Meanwhile, quantitative data analysis used $\mathrm{N}$-gain score analysis. The finding showed that: 1) the living values education model in civic education learning activity is the integration of living values into material, method, media, learning source and assessment. Implementation of living values education in Civic Education learning activities: Introduction activities (contracts of civic education classes that have a nation character through brainstorming and joint commitment); opening activities (apperception through internal reflection and delivery of learning objectives); core activities (clarification of life values, contextual learning, creative expressions of art, and habitual values ); and closing activities (making summaries and reflection); 2) The application of the model of living values education in civic education learning have a significantly effect student' civic disposition.
\end{abstract}

Keywords—civic disposition; civic education; learning; living values education; student

\section{INTRODUCTION}

The reality of life in Indonesia today showcases emerging symptoms of demoralization among the younger generation. Unfortunately, civic learning that primarily serves as a means of nation and character building and national mission to educate the nation through the corridor of "value-based education" has not yet contributed much in preventing and overcoming the problem. This is largely attributed to the heavy emphasis of civic education on mastery of cognitive materials; the dominant application of conventional learning methods such as ground covering technique, indoctrination, and narrative technique; and lack of orientation to the application of life values through value learning [1-3].

Meanwhile, in facing the global era, the chief goal of civic education is to enable students to be intelligent and creative, to recognize themselves, and develop their character and self concept [4, 5]. Strengthening the concept ultimately leads to the application of moral values and beliefs in the context of building the nation and state, which will profoundly contribute to building the character of citizens in this global era on conceptual and operational terms $[4,6]$.

Therefore, it is necessary to reconstruct a model of character education integration in civic education so as to fulfill contextual demands on the basis of living values as well as school culture, which involves such aspects as "knowing the good, desiring the good/loving the good and acting the good", all of which are incorporated into all components and learning stages of civic learning as core activities in school. One of the alternative model under development is a 'living values education model' propounded by the United Nations through UNICEF which has been widely adopted in school [7-11].

Based on the aforementioned background, the present paper seeks to address the following questions: a) how is a living values education-based civic learning model used to foster students' civic disposition? and b) how does the proposed model impact the development of students' civic disposition?

\section{METHOD}

The research is carried out by using the design of research and development. The application of Research and Development aims to develop a model of LVE in Civic Education Learning to develop the civic dispositions of students. The research was conducted through two forms of activity. They are (1) the qualitative exploration and (2) quantitative through experiment [12]. The exploration activities are used to develop and to implement the model, while the experiment is used to observe the impact of the model application.

Participants in the introduction study were students of Junior High School (SMP), teachers of civic education as practitioners, and lecturers who are experts in civic education learning. The participants of the experiment study were students of eighth grade in Junior High School 1 Lembang, Junior High School 5 Bandung, dan Junior High School Pasundan 2 Bandung, Indonesia.

Data collection instruments include (1) the observation sheet of participation/observation, (2) the documentation study, (3) focus group discussions, and (4) questionnaire. The study employed the concept of Research and Development of Borg and Gall that were adapted and modified in four stages [13]. The fourth stage includes preliminary study, preparation of 
conceptual design model, the validation/verification of the conceptual model, and the model implementation.

Qualitative data analysis covers (1) reducing the data (field reports and summarizing the relevant key points); (2) categorizing and classifying data systematically; (3) displaying the data in the form of a table or image (to explain the relationship between the data); (4) conducting cross-site analysis (by comparing and analyzing the data in depth); and (5) presenting the findings (drawing general conclusions and the implications of the implementation, as well as recommendations for development) [14]. Quantitative data analysis is performed by using $\mathrm{N}$-gain score analysis [15].

\section{RESULT AND DISCUSSION}

\section{A. Living Values Education-based Civic Learning Model}

This model was applied in school learning through a range of fun, active, creative, reflective, and value-rich learning activities, making it more meaningful to the learner's life. This learning activity does not necessarily adopt Tillman's living values education program in the form of special and separate activities but in the form of integrating the values of life and the principles of living values education in the course of study by keeping in mind the demands of materials and methods under the prevailing curriculum. The values of life that are developed are the basic values of life that emanate from Pancasila as the philosophy of the Indonesian nation. These values are explored, clarified, internalized, applied in contextual civic learning at all stages of learning activities (opening, introduction, core and closing).

The learning stages of this proposed model adopt the stages as follows $[2,8,9,16]$ :

1) Beginning. This stage covered establishing 'a class contract' done at the start of the semester, which was aimed to build the commitment of learners to make the civic class a character class that applies living values.

2) Opening. This stage included a) apperception through internal reflection and the association of life values with the materials to be studied, and b) delivery of learning objectives and plans of value-based learning activities to be undertaken.

3) Core. This was realized in a series of stages:

- Clarifying and exploring living values through VCT analysis, VCT Lists, and VCT games. This activity included a) Reception Information. Teachers invited learners to explore and explore the values from the literature, stories and positive information about the culture; b) Exploration of values in real life. Teachers used games, real-life situation/news analysis, drama/role playing, and exploration of values and how these values are to be applied; c) Imagining values and gaining experience in applying values.

- Studying facts, concepts, principles, procedures, attitudes, and behaviors according to the applicable curriculum using the contextual learning via these strategies: Project-based learning, Work-based learning, Problem-based learning, Cooperative Learning, and Service Learning. In the overall contextual learning framework, the learners discussed in groups and presented to the class the results of discussion with mutual respect, sharing, and empathy.

- Creative Expression: Art is the right medium for learners to express their ideas and feelings creatively and dig their own values. The learners exhibited art creations through yells, singing, music, dancing, poetry, pantun (traditional poetry), images, and so on.

- Internalizing values in learning through modelling, rewarding, giving warning, and appropriate sanctions.

4) Closing. Teachers and students concluded the material and reflect on the living values to be applied in life. The stages undertaken included:

- Summarizing facts, concepts, principles, procedures, living values and attitudes to be applicable in everyday life.

- Developing personal, social, and emotional skills through relaxation/concentration exercises to 'sense' those values, understand the positive qualities of individuals, and develop self-confidence through videos or motivational stories.

- Reflecting on learning materials and processes, as well as applying values in everyday life.

\section{B. The Impact of Living Values Education-based Civic Learning Model to Students' Civic Disposition}

This study examines the application of living values education model in civic learning in developing students' characters. The results of a research study at a junior high school level reveal that in each class, both experiment and control, in three junior high schools in Bandung, the character of the students improved, albeit a difference in improvement between the two classes. In the experimental class (SMP A = 0.99 , SMP B $=1.12$ and SMP C $=1.04$ ) its improvement was higher than that of the control class (SMP A $=0.34$, SMP B = 0.40 and SMP $C=0.30)$. Based on the test results of paired samples t-test, Sig. (2-tailed) is $0.000<\alpha(0.05)$. Thus, the living values-based civic education learning model here could evidently develop student civic disposition. Comparison of $n$ gain score of the experimental class and control class can be seen in the following figure [16]: 


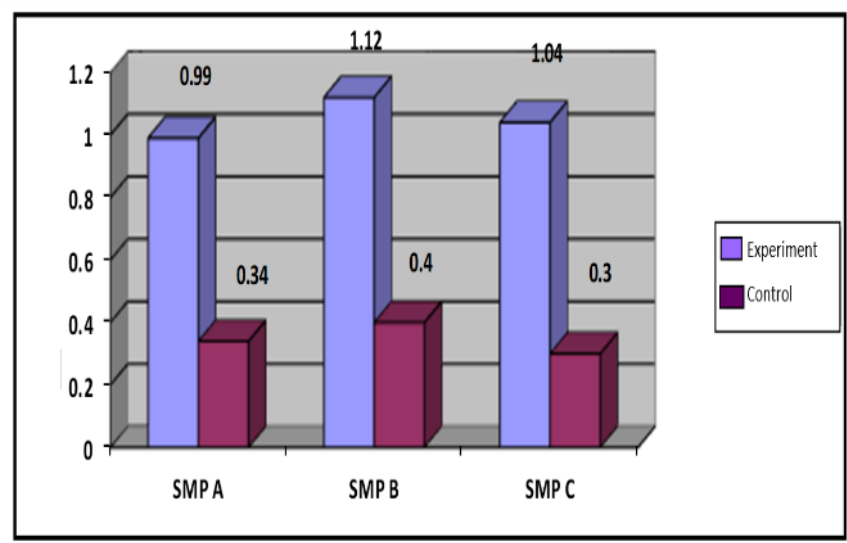

Fig. 1. Comparison of n-gain score of the experimental class and control class.

Results also show that there is a significant difference in the character improvement of the learners between the experimental class and the control class, whereby the experiment class was reportedly higher in character improvement than the control class. This illustrates the significant influence of integration of living values in civic learning on the development of student characters.

The results of this study suggest that living values education is an integral part of the education process as a whole. In this educational model, learning is at the core of the activity, and in this learning process, values are taught in the real context through habituation and modelling, making learning more meaningful for students. This accords with Hermann's statement that"...value is neither thought nor caught, it is learned" [17]. In the same vein, Halstead \& Taylor contend that the substance of values is not to be merely captured and taught but rather values are to be discerned in the sense of being captured, internalized, and standardized as an inherent part of one's personal qualities through the learning process [18]. Therefore, the process of education is basically a cultural process that allows for civilized, cultured human beings.

The integration of living values education in civic learning evidently develops students' civic disposition, since the living values in question are the values that reflect human existence in human life as creatures of God, individual beings, social beings, creatures that occupy the universe, and citizens. Civic disposition is attitudes and habit of mind of the citizen that are conducive to the healthy functioning and common good of the democratic system. Conceptually civic disposition includes a number of personality characteristics, namely: Civility (respect and civil discourse), individual responsibility, self-discipline, civic-mindedness, open-mindedness (openness, skepticism, recognition of ambiguity), compromise (conflict of principles, compassion, generosity, and loyalty to the nation and its principles [19].

When these values are reflected through a living values education-based learning model, the students will learn about their lives and play a positive role in their lives in a practical way. Character education is an active measure to establish habit. Character education is a deliberate effort that helps students to understand, care for, and acts on the basis of the core of ethical values in their life, which includes knowledge, attitudes, and moral behavior [20].

\section{CONCLUSION}

The living values education model in civic learning was carried out in the following stages: i) Beginning: a contract was made at the beginning of the semester through brainstorming and joint commitment building; ii) Opening: apperception through internal reflection and delivery of learning objectives; iii) Core: clarifying the living values through VCT; contextual learning through Project-based learning, Work-based learning, Problem-based learning, Cooperative Learning, and Service Learning; creative expression through art; and value habituation through modelling, rewarding, warning, and appropriate punishments; and iv) Closing: summarizing the facts, concepts, principles, procedures, and life values, and reflecting on learning materials and processes, and the application of values in everyday life. The application of this proposed learning model has a significant positive effect on the development of student character.

\section{ACKNOWLEDGMENTS}

The research is a grant from the Indonesia University of Education. The author would like to express sincere appreciation for all support provided.

\section{REFERENCES}

[1] J.J. Cogan and P. Morris, "The development of civics values: an overview," International Journal of Educational Research, vol. 35, pp. 19, 2001.

[2] K. Komalasari, "The Living Values-Based Contextual Learning to Develop the Students' Character,' Journal of Social Science, vol. 8, no. (2), pp. 246-257, 2012.

[3] K. Komalasari and D. Saripudin, "The Influence of Living Values Education-Based Civic Education Textbook on Student's Character Formation," International Journal of Instruction, vol. 11, no. (1), pp. 395-410, 2018.

[4] J. Youniss, S. Bales, V. Christmas-Best, M. Diversi, M. McLaughlin, and R. Silbereisen, "Youth Civic Engagement in the Twenty-First Century," Journal of Research on Adolescence, vol. 12, no. (1), pp. 121148, 2002.

[5] K.J. Kennedy, "Student Constructions of 'Active Citizenship': What does Participation mean to Students?" British Journal of Educational Studies, vol. 55, no. (3), pp. 304-324, 2007.

[6] S.E. Finkel, and A.E. Smith, "Civic Education, Political Discussion, and the Social Transmission of Democratic Knowledge and Values in a New Democracy: Kenya 2002," American Journal of Political Science, vol. 55, no. (2), pp. 417-435, 2011

[7] E. Arweck, and E. Nesbitt, "Living Values: An Educational Program from Initiative to Uptake," British Educational Research Journal, vol. 26, no. (2), pp. 133-149, 2004a.

[8] K. Komalasari, D. Saripudin, and I.M. Masyitoh, "Living Values Education Model in Learning and Extracurricular Activities to Construct the Students' Character," Journal of Education and Practice, vol. 5, no. (7), pp. 166-174, 2014.

[9] D. Saripudin and K. Komalasari, "Living Values Education in School's Habituation Program and Its Effect on Student's Character 
Development," The New Educational Review, vol. 39 , no. (1), pp. 5162, 2015.

[10] K. Komalasari and Sapriya, "Living Values Education in Teaching Materials to Develop Students' Civic Disposition," The New Educational Review, vol. 44, no. (2), pp. 107-124, 2016.

[11] K. Komalasari, and D. Saripudin, "A Model of Living Values Education-Based Civic Education Textbooks In Indonesia," The New Educational Review, vol. 47, no. (1), pp. 139-150, 2017a.

[12] J.W. Creswell, Educational Research : Planning, Conducting, And Evaluating Quantitative And Qualitative Research. Boston : Pearson Education, Inc, 2012.

[13] W.R. Borg and M.D. Gall, Educational Research: An Introduction (5th ed). New York: Longman, 1989.

[14] R.J. Fraenkel and N.C. Wallen, How to Design and Evaluate Research in Education. New York: McGraw-Hill.Inc, 1993.

[15] W.R. Shadish, T.D. Cook, and D.T. Campbell, Experimental and QuasiExperimental Design for Generalized Causal Inference. Boston: Houghton Mifflin Company, 2002.
[16] K. Komalasari and D. Saripudin, "Value-Based Interactive Multimedia Development through Integrated Practice for The Formation of Students' Character," Turkish Online Journal of Educational Technology, vol. 16, no. (4), pp. 179-186, 2017 b.

[17] Hermann, "Value Theory (Axiology)," The Journal of Value Inquiry, vol. VI, no. (3), pp. 163-184, 1972.

[18] J.M. Halstead and M.J. Taylor, "Learning And Teaching About Values: A Review Of Recent Research," Cambridge Journal of Education, vol. 30, no. (2), pp. 169-202, 2010.

[19] C.N. Quigley, Jr.J.H. Buchanan, and C.F Bahmueller, Civitas: A Framework for Civic Education. Calabasas: Center for Civic Education, 1991.

[20] E. Arweck and E. Nesbitt, "Values Education: The Development And Classroom Use Of An Educational Programme 1," British Educational Research Journal, vol. 30, no. (2), pp. 245-261, 2004b. 